\title{
How the soil chemical composition is affected by seven tree species planted at a contaminated and remediated site
}

\author{
T. Marañón, C. M. Navarro-Fernández, M. T. Domínguez, P. Madejón, and J. M. Murillo \\ Institute of Natural Resources and Agrobiology, IRNAS, CSIC, Seville, Spain \\ Correspondence to: T. Marañón (teodoro@irnase.csic.es)
}

Received: 17 September 2015 - Revised: 6 November 2015 - Accepted: 11 November 2015

- Published: 26 November 2015

\begin{abstract}
Trees modify the physico-chemical and biological properties of the soil underneath. Here we present results for seven tree species planted at a site that was contaminated by a mine spill - after which soil was cleaned up and remediated - and later was afforested. We studied the chemical composition ( 24 elements) in five ecosystem compartments (leaves, forest floor, roots, topsoil and deep soil). The variation in chemical concentration was highest at the level of canopy leaves and lowest at deep soil. The identity of tree species significantly affected the composition of all elements in the canopies but none in the deep soil underneath. Although the observed tree effects on topsoil chemistry were weak, the footprint is expected to be reinforced with age of the plantation, contributing to the phytostabilization of contaminating elements and to the carbon sequestration.
\end{abstract}

\section{Introduction}

Trees are ecosystem engineers, modifying soil physicochemical properties, nutrient cycling and microbial communities (Vesterdal and Raulund-Rasmussen, 1998; Aponte et al., 2011, 2013). The behaviour of different elements in the afforested biogeochemical landscape will depend on their sources, their chemical bonding properties and their degree of biological control (Ladanai et al., 2010).

Chemical composition of forest superficial soil is influenced mainly by leaf-fall quality, but also by atmospheric deposition, leaching and root exudates (Aponte et al., 2011). In contaminated soils, the potentially toxic elements can be partially immobilized by afforestation; this soil remediation measure is known as "phytostabilization" (Bolan et al., 2011).

The Guadiamar Green Corridor (SW Spain) is a largescale example of phytostabilization. After a mine spill (in 1998) that contaminated about 4000 ha, soil was cleaned up and remediated, and later the site was afforested with several native shrub and tree species (Domínguez et al., 2008). In this study we explored the chemical composition of five ecosys- tem compartments in the established mixed forest: canopy leaves, forest floor, tree roots, topsoil and deep soil.

The objectives were to characterize the chemical heterogeneity at canopy level, originated by planting different tree species, and to evaluate the strength of their footprint on soil properties, 16 years after plantation. Specific questions were, what was the rank of variability among chemical elements by compartment? What was the mean chemical variability by ecosystem compartment? Was there a significant difference among tree species for every chemical element by ecosystem compartment? In particular, was there a significant treespecies effect on soil?

\section{Material and methods}

The study area was the Guadiamar Green Corridor (Sevilla, Spain). Its climate is Mediterranean, with mild rainy winters and warm dry summers. Average annual temperature is $19^{\circ} \mathrm{C}$ and annual rainfall is $448 \mathrm{~mm}$. In a plot of about 14 ha $\left(37^{\circ} 23.165^{\prime} \mathrm{N} 6^{\circ} 13.668^{\prime} \mathrm{W}\right)$ we randomly selected five replicated trees of each of seven species afforested (35 tree samples in total). Three species were deciduous (Populus alba, Celtis australis and Fraxinus angustifolia) and four ever- 
Table 1. Variability of the concentration of 23 chemical elements in five ecosystem compartments: mean, maximum and minimum values of CV. Tree-species effect indicated by the number of chemical elements showing significant variability due to tree-species identity, according to the ANOVA or Kruskal-Wallis results.

\begin{tabular}{lrrrr}
\hline \multirow{2}{*}{ Ecosystem compartment } & \multicolumn{3}{c}{ Coefficient of variation } & \multirow{2}{*}{ Tree-species effect } \\
\cline { 2 - 3 } & Mean & Maximum & Minimum & \\
\hline Canopy leaves & 78.6 & 226.4 & 6.6 & 23 \\
Forest floor & 65.3 & 130.2 & 11.6 & 20 \\
Roots & 61.8 & 134.9 & 7.4 & 22 \\
Superficial soil & 25.0 & 86.2 & 11.6 & 3 \\
Deep soil & 21.9 & 65.4 & 11.1 & 0 \\
\hline
\end{tabular}

green (Quercus ilex, Olea europaea, Ceratonia siliqua and Pinus pinea). We sampled in 2014 fully expanded leaves, forest floor (litter), excavated roots, and soil at two depths: topsoil $(0-10 \mathrm{~cm})$ and deep soil $(10-30 \mathrm{~cm})$.

Soil properties within the plot were similar before afforestation, and therefore we could infer tree effects in this common garden experiment. Soil was Fluvisol type, had a loamy texture ( $42 \%$ sand and $19 \%$ clay), was acidic ( $\mathrm{pH}$ about 4$)$, and was nutrient-poor $\left(0.07 \% \mathrm{~N}, 8 \mathrm{mg} \mathrm{kg}^{-1}\right.$ available P) (site 4 in Domínguez et al., 2010).

Samples of the three plant materials and two soil layers were processed and analysed for the composition of 22 chemical elements (Al, As, B, Ba, Ca, Cd, Co, Cr, Cu, Fe, K, $\mathrm{Li}, \mathrm{Mg}, \mathrm{Mn}, \mathrm{Na}, \mathrm{Ni}, \mathrm{P}, \mathrm{Pb}, \mathrm{S}, \mathrm{Sr}, \mathrm{V}, \mathrm{Zn}$ ) by inductively coupled plasma optical emission spectrometry (ICP-OES), and of $\mathrm{C}$ and $\mathrm{N}$ by elemental analysis (see general methods in Madejón et al., 2006; Domínguez et al, 2008). A total of 23 elements were considered for plant materials ( $\mathrm{Li}$ was under detectable levels in plants) and also 23 for soil samples (B was under detectable levels in soils).

The variability in the concentration of each chemical element by ecosystem level was measured by the coefficient of variation $(\mathrm{CV})$. Elements under biological control were expected to have lower variability in plant compartments than in soil (Ladanai et al., 2010). Global chemical heterogeneity at each ecosystem level was evaluated as the mean CV of the 23 measured elements by compartment. We expected higher heterogeneity at superficial soil (more affected by leaf-fall) than at deeper soil.

The source of variation due to the tree species was tested by analysis of variance (one-way ANOVA) for each chemical element and ecosystem compartment. Previously data were tested for normality (Shapiro-Wilk test) and homoscedasticity (Levene test) and log-transformed if necessary. Alternatively a non-parametric Kruskal-Wallis test was applied. In addition to the global comparison, the chemical composition of topsoil under contrasted tree species was compared by pair-wise Student's $t$ tests. All the analyses were carried out with the STATISTICA v8.0 program (Stat Soft, Tulsa, Oklahoma, USA).

\section{Results and discussion}

\subsection{Leaves}

Tree canopies had the highest variability in the concentration of 23 elements; the mean CV was $79 \%$ (Table 1). Elements with the lowest $\mathrm{CV}$ values were C $(7 \%), \mathrm{N}(20 \%)$ and $\mathrm{K}$ $(26 \%)$, in general those under higher biological control. The highest variability was shown by Cd (226\%), Zn (158\%), $\mathrm{V}(126 \%)$ and Mn (123\%), non-limiting elements, which excess uptake was poorly regulated (Ladanai et al., 2010).

The identity of tree species was a major source of variation for the concentration of all the 23 elements in leaves (Table 1). The presence of accumulator species explained the high variability of certain elements. For example, the higher accumulation of $\mathrm{Cd}$ and $\mathrm{Zn}$ in leaves of Populus and of $\mathrm{Mn}$ in Quercus has previously been reported in the Guadiamar area (Madejón et al., 2004, 2006). We also found here a remarkable accumulation of several elements - $\mathrm{Ba}, \mathrm{Ca}, \mathrm{Cr}, \mathrm{Fe}, \mathrm{Na}$, $\mathrm{Pb}, \mathrm{Sr}$ and $\mathrm{V}-$ in the leaves of Celtis. Each tree species had a characteristic chemical composition determined by selective uptake of soil elements, differential exclusion or accumulation, and transport to leaves, which could reflect a separation in their "biogeochemical niche" (Sardans and Peñuelas, 2014).

\subsection{Forest floor}

The mass accumulated under the tree canopy was the net result of litter production and decomposition, and its chemical composition would reflect both litterfall and decomposers (Vesterdal and Raulund-Rasmussen, 1998; Ladanai et al., 2010). The forest floor heterogeneity was high (mean CV of $65 \%)$. Minimum CV value was found for C $(12 \%)$ and $\mathrm{Mg}(20 \%)$, whereas the maximum variability was presented by non-essential elements $\mathrm{Cd}(130 \%)$, As (100\%) and $\mathrm{Pb}$ (98\%).

Forest floor mirrored the chemical patterns of the canopy, with peaks of $\mathrm{Cd}$ and $\mathrm{Zn}$ under Populus; Mn under Quercus; or $\mathrm{Ca}, \mathrm{Na}$ and $\mathrm{Sr}$ under Celtis. However the tree-induced heterogeneity was attenuated, showing significant differences among tree species for 20 out of 23 elements (Table 1). 


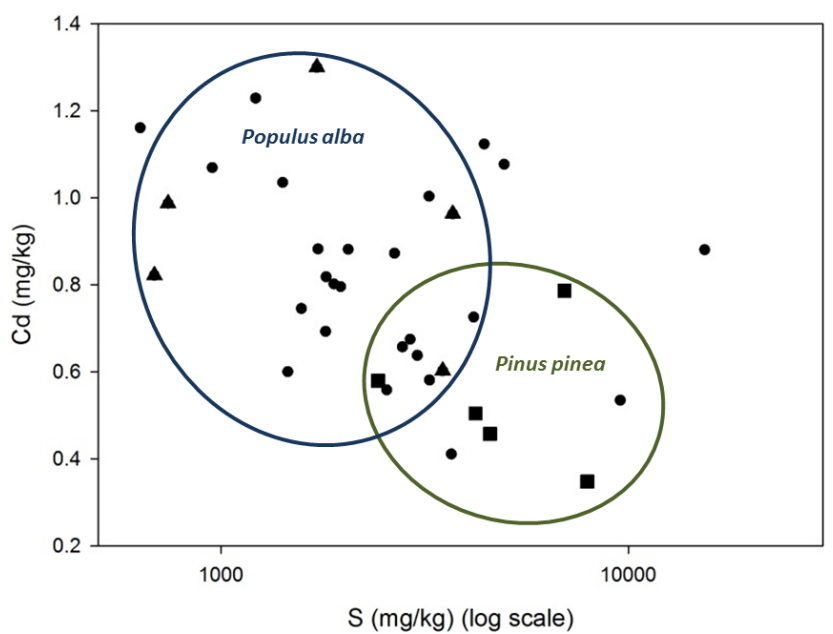

Figure 1. Bivariate diagram of the concentration of $\mathrm{Cd}$ and $\mathrm{S}$ (log scale) in the superficial soil under the 35 trees of 7 species. For illustrative purpose two contrasted species, Populus alba (triangle) and Pinus pinea (square), are indicated that showed pair-wise significant differences in $\mathrm{S}(t$ value of 2.6, $p=0.03)$ and $\mathrm{Cd}(t$ value of $-3.0, p=0.02$ ).

\subsection{Roots}

The average variability of root chemical composition was also high (mean $\mathrm{CV}$ of $62 \%$ ), with the minimum $\mathrm{CV}$ value for $\mathrm{C}(7 \%)$ and $\mathrm{P}(30 \%)$, those elements under higher biological control. In contrast, the non-essential elements $\mathrm{Cr}$ $(135 \%)$, As (94\%) and $\mathrm{Pb}(91 \%)$ presented the highest variability in roots.

Roots had also a characteristic tree-species signal with significant among-species variance for 22 out of 23 elements (Table 1). However, the pattern was quite different from leaves; for example, there was no significantly higher accumulation of $\mathrm{Cd}$ and $\mathrm{Zn}$ in Populus roots. The highest accumulation of elements - $\mathrm{Al}, \mathrm{As}, \mathrm{Cr}, \mathrm{Pb}$ and $\mathrm{V}$ - was produced in the roots of Celtis. In general, accumulation of non-essential elements in roots may reflect detoxification mechanisms by their immobilization in cell walls (Domínguez et al., 2009) or in the mycelium of mycorrhizal fungi (Wu et al., 2016).

\subsection{Superficial soil}

The heterogeneity of chemical concentration of 23 elements in topsoil was lower than in the three plant compartments; the mean CV was $25 \%$ (Table 1). Elements presenting lowest variability were $\mathrm{V}(12 \%), \mathrm{P}(13 \%)$ and $\mathrm{Fe}(13 \%)$, whereas the highest values were found for $\mathrm{S}(86 \%), \mathrm{Pb}(41 \%)$ and As $(36 \%)$. Forest soil heterogeneity is originated by changes in soil-forming factors, management and stochastic variation (Quilchano et al., 2008).

Tree-species identity was the source of significant difference for only three elements (Cd, Co and $\mathrm{Li}$ ) in topsoil. Despite the strong differences in chemical composition of leaves and roots among tree species the chemical footprint in the topsoil was weak. However, contrasted species had significant pair-wise differences in the soil underneath (detected by Student's $t$ test); for example topsoil under Pinus pinea trees had lower concentrations of $\mathrm{Cd}, \mathrm{Co}, \mathrm{Li}, \mathrm{Mn}, \mathrm{Ni}$ and $\mathrm{Zn}$ but higher concentrations of $\mathrm{S}$ than soil under Populus alba (Fig. 1).

Probably the elapsed time (16 years) was not enough to detect a significant and strong tree signal in the soil. In a review of 70 studies Li et al. (2012) found that age after plantation was a major factor explaining the dynamics of soil $\mathrm{C}$ (significantly increased after 30 years) and $\mathrm{N}$ (significant after 50 years).

\subsection{Deeper soil}

The chemical composition of deeper soil $(10-30 \mathrm{~cm})$ was even less heterogeneous; mean $\mathrm{CV}$ was $22 \%$. The least variable elements were $\mathrm{Cu}(11 \%), \mathrm{P}(12 \%)$ and V (12\%), whereas the highest heterogeneity was presented by $\mathrm{S}$ (65\%), $\mathrm{Na}(37 \%)$ and $\mathrm{Cd}(34 \%)$. There was no significant effect of the species of tree planted aboveground for any chemical element in that deeper horizon (Table 1). In general, the tree effects on soil nutrients tend to disappear with depth, and subsoil features are frequently used as proxy of the original soil conditions (Aponte et al., 2013).

\section{Conclusions}

In conclusion, the chemical footprint in the soil by the seven tree species was still weak, partly due to their young age (only 16 years after plantation). However, those trees planted in a contaminated and remediated soil are contributing effectively to the phytostabilization of trace elements by their immobilization in roots and organic matter, and to the carbon sequestration in biomass and soil, thus providing valuable ecosystem services.

Acknowledgements. Thanks to J. M. Alegre for helping during sampling and to P. Burgos for chemical analyses. The research leading to these results has received funding from the European Union Seventh Framework Programme (FP7/2007-2013) under grant agreement no. 603498 (RECARE) and from the Spanish RESTECO (CGL2014-52858-R) project.

Edited by: D. Montesinos

Reviewed by: two anonymous referees

\section{References}

Aponte, C., García, L. V., Pérez-Ramos, I. M., Gutiérrez, E., and Marañón, T.: Oak trees and soil interactions in Mediterranean forests: a positive feedback model, J. Veg. Sci., 22, 856-867, 2011. 
Aponte, C., García, L. V., and Marañón, T.: Tree species effects on nutrient cycling and soil biota: a feedback mechanism favouring species coexistence, Forest Ecol. Manage., 309, 36-46, 2013.

Bolan, N. S., Park, J. H., Robinson, B., Naidu, R., and Huh, K. Y.: Phytostabilization: A green approach to contaminant containment, Adv. Agron., 112, 145-204, 2011.

Domínguez, M. T., Marañón, T., Murillo, J. M., Schulin, R., and Robinson, B. H.: Trace element accumulation in woody plants of the Guadiamar Valley, SW Spain: A large-scale phytomanagement case study, Environ. Pollut., 152, 50-59, 2008.

Domínguez, M. T., Madrid, F., Marañón, T., and Murillo, J. M.: Cadmium availability in soil and retention in oak roots: Potential for phytostabilization, Chemosphere, 76, 480-486, 2009.

Domínguez, M. T., Madejón, P., Marañón, T., and Murillo, J. M.: Afforestation of a trace-element polluted area in SW Spain: woody plant performance and trace element accumulation, Eur. J. For. Res., 129, 47-59, 2010.

Ladanai, S., Ågren, G. I., and Olsson, B. A.: Relationships between tree and soil properties in Picea abies and Pinus sylvestris forests in Sweden, Ecosystems, 13, 302-316, 2010.

Li, D., Niu, S., and Luo, Y.: Global patterns of the dynamics of soil carbon and nitrogen stocks following afforestation: a metaanalysis, New Phytol., 195, 172-181, 2012.
Madejón, P., Marañón, T., Murillo, J. M., and Robinson, B.: White poplar (Populus alba) as a biomonitor of trace elements in contaminated riparian forests, Environ. Pollut., 132, 145-155, 2004.

Madejón, P., Marañón, T., and Murillo, J. M.: Biomonitoring of trace elements in the leaves and fruits of wild olive and holm oak trees, Sci. Total Environ., 355, 187-203, 2006.

Quilchano, C., Marañón, T., Pérez-Ramos, I. M., Noejovich, L., Valladares, F., and Zavala, M. A.: Patterns and ecological consequences of abiotic heterogeneity in managed cork oak forests of Southern Spain, Ecol. Res., 23, 127-139, 2008.

Sardans, J. and Peñuelas, J.: Climate and taxonomy underlie different elemental concentrations and stoichiometries of forest species: the optimum "biogeochemical niche", Plant Ecol., 215, 441-455, 2014.

Vesterdal, L. and Raulund-Rasmussen, K.: Forest floor chemistry under seven tree species along a soil fertility gradient, Can. J. Forest Res., 28, 1636-1647, 1998.

Wu, S., Zhang, X., Chen, B., Wu, Z., Li, T., Hu, Y., Sun, Y., and Wang, Y.: Chromium immobilization by extraradical mycelium of arbuscular mycorrhiza contributes to plant chromium tolerance, Environ. Exp. Bot., 122, 10-18, 2016. 